\title{
Dimensioning of the physical area and required number of food handlers for school food services
}

\section{Dimensionamento da área física e do número de manipuladores de alimentos de serviços de alimentação escolar}

\author{
Diogo Thimoteo da CUNHA' ${ }^{1}$ (D) 0000-0001-5928-9265 \\ Ana Laura Benevenuto de AMORIM² (iD 0000-0003-0745-8201 \\ Fernanda Helena Marrocos LEITE ${ }^{3}$ (iD) 0000-0003-0470-1974 \\ Elke STEDEFELDT ${ }^{4}$ (iD) 0000-0003-1136-5374 \\ Veridiana Vera de ROSSO 5 (iD 0000-0001-7327-7471 \\ Daniel Henrique BANDONI² (iD) 0000-0003-1638-1437
}

\section{A B S T R A C T}

\section{Objective}

We aimed to establish equations for dimensioning of the physical area and determining the required number of food handlers in food services of schools and to compare them with reference equations.

\footnotetext{
${ }^{1}$ Universidade Estadual de Campinas, Faculdade de Ciências Aplicadas, Laboratório Multidisciplinar em Alimentos e Saúde. R. Pedro Zaccaria, 1300, Jd. Santa Luzia, 13484-650, Limeira, SP, Brasil. Correspondence to: DT CUNHA. E-mail <diogo.cunha@fca.unicamp.br>.

2 Universidade Federal de São Paulo, Instituto Saúde e Sociedade, Departamento de Saúde, Clínica e Instituições. Santos, SP, Brasil.

${ }^{3}$ Universidade Federal de São Paulo, Instituto Saúde e Sociedade, Centro Colaborador em Alimentação e Nutrição Escolar. Santos, SP, Brasil

${ }^{4}$ Universidade Federal de São Paulo, Centro de Desenvolvimento do Ensino Superior em Saúde, Escola Paulista de Enfermagem. São Paulo, SP, Brasil.

5 Universidade Federal de São Paulo, Instituto Saúde e Sociedade, Departamento de Biociências. Santos, SP, Brasil. Support: Ministério da Educação, Fundo Nacional de Desenvolvimento da Educação (Termo de Cooperação nº 17194/2013).
}

\section{How to cite this article}

Cunha DT, Amorim ALB, Leite FHM, Stedefeldt E, Rosso VV, Bandoni DH. Dimensioning of the physical area and required number of food handlers for school food services. Rev Nutr. 2019;32:e180188. http://dx.doi.org/10.1590/1678-9 $865201932 e 180188$ 


\section{Methods}

It was visited 44 municipalities located in the states of São Paulo $(n=36)$ and Rio de Janeiro $(n=8)$ between 2013 and 2014. The physical area for school food services was evaluated using a measuring tape. For all food services, we calculated the Maximum Attendance Capacity, which is the sum of small and large meals served during the busiest shift. A validated checklist was used to evaluate food safety practices. Linear regression models were developed to establish the proposed equations.

\section{Results}

In total, we evaluated 205 school units. Based on the data, the following equations were established: Equation $A$ : area of production $=15.22+$ (maximum attendance capacity $\times 0.02$ ), which estimates the minimum area needed for a school food service; and Equation B: the number of food handlers=2.17+(maximum attendance capacity $\times 0.002)$, to determine the minimum number of food handlers needed. These equations were established based on school food services that presented adequate food safety practices (i.e., low health risk).

\section{Conclusion}

It was established new equations for calculating the size of the physical area for school food services and the required number of food handlers. These new equations can be used as a starting point in management planning of a school food service.

Keywords: Collective feeding. Food handling. School feeding.

\section{RE S U M O}

\section{Objetivo}

Estabelecer equações para o dimensionamento da área física e do número de manipuladores em serviços de alimentação escolar comparando-as com equações de referência.

\section{Métodos}

Foram visitados, entre 2013 e 2014, 44 municípios localizados nos estados de São Paulo (n=36) e Rio de Janeiro (n=8). A área útil dos serviços de alimentação escolar foi avaliada por meio de uma trena. Para todas as unidades foi calculada a Capacidade Máxima de Atendimento que é a soma das pequenas e grandes refeições servidas no turno de maior movimento. Para a avaliação das boas práticas de manipulação de alimentos foi utilizada uma lista de verificação validada. As equações foram estabelecidas por meio de regressão linear com base em serviços de alimentação escolar que apresentaram boa adequação das boas práticas (i.e. baixo risco sanitário).

\section{Resultados}

Foram avaliados 205 serviços de alimentação escolar. Com base nos dados foi determinada a Equação $A$ : $m^{2}$ da área de produção=15,22+(Capacidade máxima de atendimento×0,02) que estima a área mínima para um serviço de alimentação escolar e a Equação B: número de manipuladores=2,17+(Capacidade máxima de atendimentox0,002) para o número mínimo de manipuladores de alimentos.

\section{Conclusão}

Novas equações para cálculo do dimensionamento da área física de serviços de alimentação escolar e para o número de manipuladores de alimentos necessários foram estabelecidas. Essas novas equações podem ser utilizadas como ponto de partida para o planejamento gerencial de um serviço de alimentação escolar.

Palavras-chave: Alimentação coletiva. Manipulação de alimentos. Alimentação escolar.

\section{NTRODUCTION}

The collective food service area is an area of activity for nutritionists that covers the nutritional care of occasional or defined groups of healthy or ill people [1]. The nutritionist in collective food services should plan and provide nutritionally balanced foods and be able to coordinate the production of safe food and meals [2]. 
To fulfill the steps for supplying such meals, an adequate layout of the food service area is fundamental. The layout, in a food service context, is defined as the set of food processing areas and areas for food distribution and consumption and for returning trays (the refectory). An adequate layout allows for adequate production flows (e.g., raw material and personnel flows) and the placement of equipment, considering interferences to an approach focused not only on production but also on health, to minimize possible risks of Foodborne Diseases (FBD) [3]. An inadequate physical area and layout can lead to problems that are difficult to correct, such as decreased productivity, increased work accidents, more failures to properly execute procedures, more food safety violations, and increased work-related illnesses [4]. It has been observed that an adequate physical structure is an important determinant of food safety practices in restaurants [2].

Researchers have developed equations to assist in the design of Unidades de Alimentação e Nutrição (UAN, Food and Nutrition Units) (known as food services or catering in English), such as those defined by Teixeira et al. [4] in 1992, Gandra \& Gambardella [5] in 1986, and Sant'Ana \& Campos [6] in 2012. These formulas are generic, i.e., they were developed considering food services in general. However, it is understood that food service in the school environment has specific requirements regarding management, such as optimized size of food services, menu composition, origin of food items, and consumers of varying ages, among others.

In this sense, specific equations should be proposed for school food services using current and good quality reference standards. Food safety is an important indicator of quality in food services, and thus may be a benchmark in new equations. Food safety is also sensitive to other important indicators, such as the number of employees and physical area of food services [2].

According to the latest data from the Fundo Nacional de Desenvolvimento da Educação (FNDE, National Fund for Education Development), which is financially responsible for the School Feeding Program in Brazilian public schools, 3.759 billion Brazilian Reais were invested in 2015 to serve 41.5 million students in basic education (from kindergarten to high school) [7]. However, in most cases, meals offered to students in basic education are prepared in food services located within schools that are sometimes in precarious situations, mainly because the food services are similar to domestic kitchens and have not been previously or adequately planned [8]. The responsibility of the nutritionist is even greater in this context, as most students in these schools consume the offered meals, especially at lunch [9].

Several articles have been published regarding failures and food safety violations in Brazilian public schools [10-12]. It is hoped that using appropriate reference equations, those responsible for school food services, especially nutritionists who are the technical leaders in school feeding programs [13], will have greater support in making decisions and planning the physical area of school food services.

The objective of this study was to establish equations for the dimensioning of the physical area and the required number of food handlers in school food services, and to compare them with reference equations.

\section{METHODS}

\section{Location and sample}

We visited a total of 44 municipalities located in the states of São Paulo ( $n=36 ; 5.6 \%$ of the total municipalities) and Rio de Janeiro ( $n=8 ; 8.7 \%$ of the total municipalities) during 2013 and 
2014. The municipalities were randomly selected. The selection was proportional to the number of municipalities and regions in each state, taking into account their different mesoregions. The final sample included, in the State of São Paulo, the following number of municipalities per mesoregion: Araçatuba=1; Assis=1; Baixada Santista=2; Bauru=1; Campinas=4; Litoral Sul Paulista=1; Macro Metropolitana Paulista=3; Marília=1; Metropolitana de São Paulo=3; Presidente Prudente=4; Ribeirão Preto=2; São José do Rio Preto=3; Vale do Paraíba Paulista=4. In the State of Rio de Janeiro the final sample comprised the following number of municipalities per mesoregion: Centro Fluminense $=2$; Metropolitana do Rio de Janeiro=3; Norte Fluminense=1; Sul Fluminense=2.

In each municipality, five public schools were randomly selected to be visited, with at least one of these located in a rural area. The schools were of different modalities and included state schools whenever the municipality presented a network delegation (i.e., when the state delegates the responsibility of state school to the municipal administration). In some municipalities, the number of schools was lower than stipulated owing to a lack of schools in rural areas or because the municipality had fewer than five schools in total.

Schools visits in each municipality were carried out by two nutritionists who were trained is use of the forms and evaluations. The research was conducted within the scope of work carried out by the Centro Colaborador em Alimentação e Nutrição Escolar (CECANE, Collaborating Center on Feeding and School Nutrition).

\section{Assessment of basic information and physical area}

The nutritionist responsible for the school feeding program of the municipality followed the visit at each school. At that time, the nutritionist was asked about the number of meals served at each meal time (breakfast, morning snack, lunch, afternoon snack, dinner, and supper) and shift (morning, afternoon, and evening), the number of food handlers, the number of students in the school, when the school food service was constructed (year), the location (urban or rural), and whether the food service had undergone any reforms. The information was recorded, checked, and confirmed with food handlers and school principals.

For evaluation of the physical area (length) of the school food service, a precision 5-m long measuring tape (in centimeters) was used. The walls of the production area (where food was handled and prepared) were measured and the floor plan of the food service was drawn on graph paper. The physical area (in square meters $-\mathrm{m}^{2}$ ) was obtained via calculating the area.

The Maximum Attendance Capacity (MAC) was calculated for all school food services. The MAC is defined as the sum of small and large meals served during the busiest shift (morning, afternoon, or evening) [6].

\section{Evaluation of food safety and physical structure}

For the evaluation of food safety practices, we used a specific checklist for evaluating school food services, developed by Stedefeldt et al. [14]. The checklist consists of 99 questions divided into 6 thematic blocks: buildings and facilities, controlled-temperature equipment, food handlers, suppliers, processes and procedures, and environmental hygiene. Scores ranging from 0 to 8 were assigned for each checklist question based on the degree of risk and importance to food safety. All scores of 0 indicated a food safety violation. After calculating the scores for each block, the results 
were summed. Thus, each school received a block score and a final score, and risk level was rated according to block score or total score, as follows: very high (0-25 points), high (26-50), regular (51-75), low (76-90), and very low (91-100) risk.

\section{Establishing equations for dimensioning the food service physical area and deter- mining the required number of food handlers}

To establish mathematical models for dimensioning the physical area and determining the number of food handlers needed, we developed linear regression models. The models were composed of linear equations $(Y=\beta 0+\beta 1 X)$ in which the value of $Y$ is the physical area $\left(\mathrm{m}^{2}\right)$ in Equation $A$ and the number of food handlers in Equation B. Variables that could influence these values were tested, such as the number of meals produced, MAC, food safety scores (per block and final score), and other basic information of school food services.

Those food services with a food safety score less than 75 points for the blocks buildings and facilities and processes and procedures were excluded from the sample because they were not considered a good reference with which to establish the equations.

\section{Reference indexes for calculating the food service physical area and required number of food handlers}

The estimated food service physical area (in $\mathrm{m}^{2}$ ) was calculated according to (a) Teixeira et al. [4]; and (b) Sant'Ana \& Campos [6], and the number of food handlers was calculated according to (c) Gandra \& Gambardella [5]. Although the reference equations proposed by Teixeira et al. [4] and Gandra \& Gambardella [5] are relatively old, they are still used in practice.

a) The estimate suggested by Teixeira et al. [4] is obtained with the total number of meals produced per day multiplied by an index (Equation 1), adjusted according to the number of produced meals (Table 1).

Table 1. Adjusted indexes for the calculation of the production area of food services according to Teixeira et al. [4]. Santos (SP), Brazil, 2014.

\begin{tabular}{lccccc}
\hline \multirow{2}{*}{$\begin{array}{l}\text { Adjusted indexes for } \\
\text { the production area }\end{array}$} & \multicolumn{5}{c}{ Meals produced per day } \\
\cline { 2 - 6 } & 100 & 300 & 500 & 1,000 & 3,000 \\
\hline $\ln \mathrm{m}^{2}$ & 0.28 & 0.10 & 0.15 & 0.11 & 0.06 \\
\hline
\end{tabular}

Note: $\mathrm{m}^{2}:$ Squared meters.

Therefore, the adjusted index was multiplied by the number of meals to estimate the food service production area, considering one of six ranges: up to 100; 101 to 300; 301 to 500; 501 to 1,$000 ; 1,001$ to 3,000 . and over 3,000 meals.

Equation 1: $\mathrm{m}^{2}$ of production area $=$ Adjusted index $\times$ Number of meals

b) The Sant'Ana \& Campos [6] estimate uses the MAC value of each food service. Those authors state that for each reduction of 200 meals in relation to the 2,000 reference value, a correction index 
must be applied, increasing the calculated value by $10 \%$. For each increase of 500 meals in the MAC above the 2500 reference value, it is necessary to reduce the value by $2 \%$ of the value of the calculated area. Once the MAC was calculated for each food service, the MAC was multiplied by 0.07 and the value adjusted, as described below (Equation 2):

Equation 2: $\mathrm{m}^{2}$ of cooking area in healthy groups $=0.07 \mathrm{~m}^{2} \times \mathrm{MAC}+$ Correction index

c) For the reference calculation to estimate the required number of food handlers, we used the equation developed by Gandra \& Gambardella [5], defined as the Fixed Personnel Index (FPI) (Equation 3).

$$
\text { Equation 3: FPI }=\frac{\text { (Number of meals per day } \times 15 \text { minutes) }}{\text { (Daily workday in minutes) }}
$$

This equation considers an average time of 15 minutes for the preparation of each meal. The daily workday in minutes was defined as 360 minutes, considering the 6 hours of daily work done in school food services by each food handler.

\section{Statistical analyses}

The equations were obtained through application of linear models. First, Pearson's correlation $(r)$ and dispersion graphs of the variables of interest were evaluated with the variables physical area (in $\mathrm{m}^{2}$ ) and number of food handlers. Variables with $>0.20$ were tested and were retained in the model when they had a statistically significant coefficient of regression $(p<0.05)$. Inclusion of variables in the model was done stepwise with forward selection. The model fit was verified using residuals analysis.

A paired Student $t$-test was used to compare the reference estimates with the estimates established using the developed equations. The Student $t$-test was used to compare two independent groups. For all quantitative variables, distribution histograms, mean, median, standard deviation were analyzed, and the Kolmogorov Smirnov test (with Lilliefors correction) was used to verify normal distribution.

Statistical tests were performed using Statistical Package for the Social Sciences software, version 15.0.1 (SPSS Inc., Chicago, Illinois, United States), with a significance level of 5\%.

\section{RESULTS AND DISCUSSION}

In total, we evaluated 204 school food services in 44 municipalities in the states of São Paulo and Rio de Janeiro, of which 186 (91.2\%) were located in urban areas and $18(8.8 \%)$ in rural areas. Table 2 presents descriptive analysis of the evaluated school food services.

The mean number of produced meals/day was 628. Despite high dimensionality the data, with a minimum of 17 and a maximum of 6186 meals/day (Table 2), the coefficient of variation was low $(0.97 \%)$. The number of meals varied according to the number of students in the school and also the type of meals offered (i.e., breakfast, lunch, snacks, and dinner). Of the total schools evaluated, 34 $(17.0 \%)$ offered only one meal per shift and 170 (83.0\%) offered two meals per shift. The regulations of the Programa Nacional de Alimentação Escolar (PNAE, National School Feeding Program) differentiate nutritional recommendations according to the number of meals offered per shift [13]. 
Table 2. Descriptive analysis of the food services of urban and rural schools. Santos (SP), Brazil, 2014.

\begin{tabular}{|c|c|c|c|c|c|c|c|c|c|c|}
\hline \multirow{2}{*}{$\begin{array}{l}\text { Dimensioning and } \\
\text { production indicators }\end{array}$} & \multicolumn{5}{|c|}{ Total of schools $(\mathrm{N}=204)$} & \multicolumn{2}{|c|}{$\begin{array}{l}\text { Urban schools } \\
\qquad(n=186)\end{array}$} & \multicolumn{2}{|c|}{$\begin{array}{l}\text { Rural schools } \\
\qquad(n=18)\end{array}$} & \multirow{2}{*}{$p$ value } \\
\hline & $\mathrm{M}$ & SD & Median & Min & Max & $\mathrm{M}$ & SD & $\mathrm{M}$ & SD & \\
\hline Total meals/day & \multicolumn{2}{|c|}{$627.6 ; 645.5$} & 500 & 17 & 6186 & \multicolumn{2}{|c|}{$662.4 ; 662.9$} & \multicolumn{2}{|c|}{$240.1 ; 172.3$} & 0.008 \\
\hline Number of students & \multicolumn{2}{|c|}{$477.9 ; 627.2$} & 274 & 8 & 6448 & \multicolumn{2}{|c|}{$505.7 ; 649.5$} & \multicolumn{2}{|c|}{$181.3 ; 169.7$} & 0.030 \\
\hline MAC & \multicolumn{2}{|c|}{$375.0 ; 461.1$} & 260 & 16 & 4835 & \multicolumn{2}{|c|}{$392.5 ; 476.5$} & \multicolumn{2}{|c|}{$162.6 ; 105.5$} & 0.040 \\
\hline Physical area (in $\mathrm{m}^{2}$ ) & \multicolumn{2}{|c|}{$25.8 ; 19.3$} & 22.0 & 3.7 & 177.1 & \multicolumn{2}{|c|}{$26.5 ; 19.7$} & \multicolumn{2}{|c|}{$18.0 ; 11.9$} & 0.090 \\
\hline Number of food handlers & \multicolumn{2}{|c|}{$3.0 ; 1.72$} & 3 & 1 & 12 & \multicolumn{2}{|c|}{$3.1 ; 1.7$} & \multicolumn{2}{|c|}{$2.1 ; 1.2$} & 0.010 \\
\hline
\end{tabular}

Note: MAC: Maximum Attendance Capacity; SD: Standard Deviation; Min: Minimum value; Max: Maximum value; M: Mean.

Several factors affect students' adherence to school meals, such as family income, parents' education level, school location, students' age, and presence of a canteen in the school, among others $[15,16]$. It is important that when planning new units or estimating the number of necessary food handlers, professionals - especially nutritionists - consider the number of meals or similar indicators, as benchmarks, and not only the number of students.

The average physical area of food services was $25.8 \mathrm{~m}^{2}$, with a low variation coefficient $(1.33 \%)$. It was expected that the size of the physical area, in general, correlates with the number of meals produced per day. A positive correlation was observed between the physical area and number of meals produced per day $(r=0.48, p<0.01)$ and $\operatorname{MAC}(r=0.46, p<0.01)$. The main factors that determine the kitchen size of a restaurant, in general, are the service type (a la carte, fast food, cafeteria, and so on) and the number of meals served per day [17]. Another important factor in estimating the size of the physical food service area is the complexity of the menu. In school food services, however, this factor is less important as school food services generally produce simple-serving menus, in which a meal is composed of a grain (usually rice), a legume (usually beans), a protein preparation, a vegetable base, and sometimes a dessert [18].

Food safety in school food services in Brazil has been investigated in several studies, in the context of evaluation $[10,11,19]$ as well as in the intervention context [20]. The average final food safety score in our study was 80.5, classifying the included schools as having a low FBD risk and indicating good compliance with food safety regulations, in comparison with previous studies (Table 3). This result shows that most of the evaluated school food services can be considered good references with respect to food safety and these may consequently represent a good sample with which to develop the proposed equations. The food safety evaluation in this study considered the FBD risk and not only the percentage adequacy of each item, i.e., we took into account concepts such as the probability and severity of each violation. The use of risk scores, with mathematical weights that approximate assessment, in a real context of FBD outbreak risk, is recommended [21] and may predict FBD outbreaks [22].

Significant differences were observed between urban and rural schools for the blocks, "buildings and facilities" and "environmental hygiene" in the food safety evaluation. Many rural schools are small, mainly due to the low demand of students. In smaller food services, compliance with food safety regulations is more complex, especially regarding adequacy of the physical structure [2]. 
Table 3. Food safety score of school food services from São Paulo and Rio de Janeiro states (N=204). Santos (SP), Brazil, 2014

\begin{tabular}{|c|c|c|c|c|c|c|c|c|}
\hline \multirow{2}{*}{ Blocks } & \multicolumn{5}{|c|}{ Total of schools $(\mathrm{N}=204)$} & $\begin{array}{l}\text { Urban schools } \\
\qquad(n=186)\end{array}$ & $\begin{array}{l}\text { Rural schools } \\
\quad(n=18)\end{array}$ & \multirow[t]{2}{*}{$p$ value } \\
\hline & M & SD & Median & Min & Max & M SD & M SD & \\
\hline Suppliers & \multicolumn{2}{|c|}{$66.09 ; 34.0$} & 50 & 0 & 100 & $66.9 ; 34.0$ & $55.5 ; 33.8$ & 0.15 \\
\hline Buildings and facilities & \multicolumn{2}{|c|}{$87.20 ; 7.7$} & 89.2 & 59 & 100 & $87.8 ; 7.2$ & $79.8 ; 8.6$ & 0.01 \\
\hline Controlled-temperature equipment & \multicolumn{2}{|c|}{$80.90 ; 39.4$} & 100 & 0 & 100 & $81.7 ; 38.7$ & $72.2 ; 46.0$ & 0.32 \\
\hline Food handlers & \multicolumn{2}{|c|}{$83.50 ; 14.7$} & 86.4 & 33.3 & 100 & $83.6 ; 14.8$ & $84.3 ; 12.66$ & 0.91 \\
\hline Processes and Procedures & \multicolumn{2}{|c|}{$81.20 ; 6.7$} & 81.7 & 62 & 97 & $81.3 ; 6.9$ & $80.6 ; 3.9$ & 0.51 \\
\hline Environmental hygiene & \multicolumn{2}{|c|}{$81.20 ; 14.3$} & 83.3 & 30 & 100 & $82.1 ; 14.3$ & $72.7 ; 12.6$ & 0.01 \\
\hline Final score & \multicolumn{2}{|c|}{$80.50 ; 9.3$} & 82.3 & 30.7 & 95.6 & $80.8 ; 9.4$ & $78.0 ; 8.64$ & 0.14 \\
\hline
\end{tabular}

Note: SD: Standard Deviation; Min: Minimum value; Max: Maximum value; M: Mean.

We observed a weak correlation between the production area and the buildings and facilities block in food safety evaluation $(r=0.16, p=0.02)$. As mentioned, a larger production area may result in better compliance. There was no correlation between scores for the other food safety blocks and the number of food handlers or physical area.

Fifteen schools were excluded from the sample for model development because they had scores less than 75 in the buildings and facilities block. Urban and rural schools were treated as a single universe as the differences between them were derived mainly from the size of the food service and from the building and facilities block score. Due to their nature, rural schools serve fewer students, and they have characteristics similar to urban schools of equal size.

We tested models in which the independent variable was the total number of meals or MAC. The model developed using the MAC had greater explanatory power, so Equation A was established as:

$$
\text { Equation } \mathrm{A}: \mathrm{m}^{2} \text { of food service production area }=15.22+(\mathrm{MAC} \times 0.02)
$$

The developed equation has a constant=15.22. This value was established using linear regression analysis and may prevent calculation of a food service area size smaller than $15.22 \mathrm{~m}^{2}$. Based on Equation A, we calculated the square meterage of each unit. Table 4 presents comparisons of the estimates calculated using different equations.

The values estimated using Equation A did not differ from those obtained using the tape measure. This result was expected because the raw data of Equation A were derived from physical measurement. The estimate calculated using the equation of Teixeira et al. [4] presented the highest value. This index is a relatively old reference and in the year when that equation was conceived, the level of food service equipment technology was lower than present day. In addition, municipalities and governments are currently applying the principle of economicity, i.e., optimization of processes, yielding improved production with the lowest possible financial cost. The estimate according to the equation of Sant'Ana \& Campos [6] was also higher than the measured meterage, but less dissimilar than the estimates made using Teixeira et al. [4] equation. 
Table 4. Evaluated and physical area (in meters) of production area and number of food handlers of school food services. Santos (SP), Brazil, 2014.

\begin{tabular}{|c|c|c|c|c|}
\hline Evaluated and estimated variables & Mean & Median & SD & $p$ value \\
\hline Physical area measured in loco & $25.8 \mathrm{~m}^{2}$ & $22.0 \mathrm{~m}^{2}$ & $19.3 m^{2}$ & - \\
\hline \multicolumn{5}{|l|}{ Estimated physical area } \\
\hline by Equation $\mathrm{A}$ & $25.6 \mathrm{~m}^{2}$ & $22.4 m^{2}$ & $10.0 \mathrm{~m}^{2}$ & 0.84 \\
\hline by Teixeira et al. [4] & $83.5 m^{2}$ & $78.0 \mathrm{~m}^{2}$ & $49.6 m^{2}$ & $<0.001$ \\
\hline by Sant'Ana \& Campos [6] & $35.7 m^{2}$ & $27.0 \mathrm{~m}^{2}$ & $29.9 m^{2}$ & $<0.001$ \\
\hline Number of food handlers evaluated in loco & $3.08(n)$ & $3.00(n)$ & $1.73(n)$ & \\
\hline \multicolumn{5}{|l|}{ Estimated number of food handlers } \\
\hline by Equation $B$ & $2.92(n)$ & $2.60(n)$ & $1.72(n)$ & 0.08 \\
\hline by FPI Gandra \& Gambardella [5] & 26.15(n) & 20.08(n) & 26.89(n) & $<0.001$ \\
\hline
\end{tabular}

Note: FPI: Fixed Personnel Index; $\mathrm{m}^{2}$ :Squared meters; SD: Standard Deviation.

Government entities are expected to promote budgetary, financial, and asset efficiency, as defined in the Federal Constitution of Brazil [23]. That is, states and municipalities must guarantee the rights of the population, such as the right to adequate food, but must minimize spending at the same time [24]. Overestimation of the physical area needed for school food services may result in economic losses to municipalities owing to the cost of purchasing the resources needed for the construction and maintenance of facilities that are larger than necessary. The index developed by Sant'Ana \& Campos [6] can be used in the school food service context, but our Equation A seems closer to the reality in public schools. In general, the structural conditions of school food services are rated poorly $[8,19]$; however, it should be emphasized that in developing Equation A, we only included those school food services with low FBD risk, yielding a reduced food service area but without sacrificing food safety. Figure 1 shows a floor plan and layout proposal for a school food service elaborated according to Equation A for 240 meals, totaling $20 \mathrm{~m}^{2}$ of production area. The other areas were designed to comply with food safety regulation RDC 216/2004 [25].

To estimate the required number of food handlers, we developed Equation B. School food services with scores below 75 points in the processes and procedures block $(n=32)$ were excluded from this model. This cutoff point was determined because the block processes and procedures contained the largest amount of violations involving critical points in food handling, and all of them were related to food handler practices. Such information is relevant, as most outbreaks involving food occur due to inadequate food handling [26]. Thus, as for Equation A, the MAC was the independent variable that had the greatest association with the number of food handlers. Therefore, Equation $B$ was defined as:

Equation B: Number of food handlers $=2.17+($ MAC $\times 0.002)$

Considering the constant of 2.17, no school food service would have less than two food handlers, even those providing very few meals (Table 3 ). In the example already presented, a school food service with a MAC of 240, three food handlers would be required. In both equations, it is recommended to round up decimal values above 0.51 . 
A

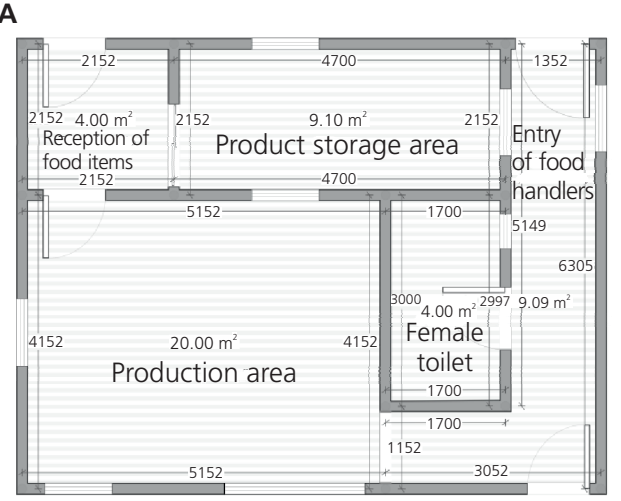

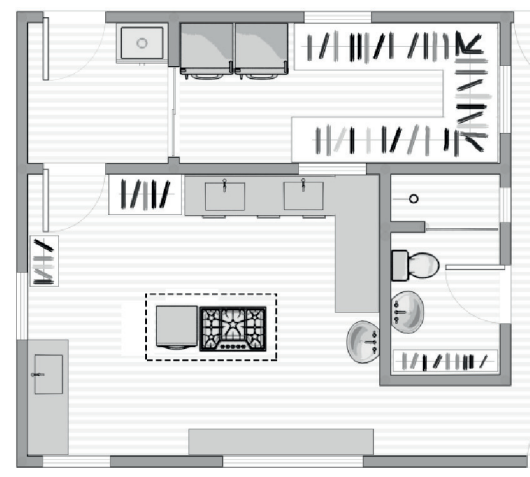

Oven

Refrigerador

I/IIr Lockers

Sink

Sink for

hand washing

Industrial oven

D Toilet

Stainless steel workbench

Sink

- Shower

Stove hood

Figure 1. Floorplan (A) and layout proposal (B) of a school food service estimated for 240 meals according to the Equation A. Santos (SP), Brazil, 2014.

The FPI generated an estimate nine times higher than the number of food handlers observed. This discrepancy was probably also attributable to technological developments in the food service area [27]. Many foodstuffs are now purchased pre-processed (i.e., sliced, cut, sanitized, seasoned) or are processed foods (e.g., potato flakes for mashed potatoes), which optimizes the work of food handlers. In the context of public services, a lack of proper budgetary planning may lead to financial crises in states and municipalities. Therefore, it is the duty of those responsible for school feeding programs maintain cost-efficiency and to adequately plan the needs of each food service in the program.

The sampled universe was composed of schools in municipalities located in the southeast region and may present a different reality from those found in other states. However, it should be emphasized that the equations were developed considering school food services with low FBD risk in relation to structural aspects and procedures, which should be inherent to all food services regardless of their location. An adequate structure that allows for adequate practices in food handling must be encouraged throughout Brazil.

\section{CONCLUSION}

We proposed new equations for calculating the physical area size of school food services and the required number of food handlers. These new equations can be used as a starting point for management planning of a school unit. Although the proposed equations have been developed by considering only public schools, the equations can be used for private schools that have similar characteristics with respect to complexity of the menu and the food service.

Research and methods are needed that can equip nutritionists to meet the legal and ethical requirements of their work, which will benefit the promotion and protection of the population's health. Equations and models, such as those proposed in this article, complement the knowledge and experience of professionals. The proposed equations will be best used as initial estimates, to guide decision-making of professionals involved in food service planning.

We observed that older equations tended to overestimate the physical area and number of food handlers needed, within the context of modern school food services, which may lead to higher 
resource expenditures or poor structural planning. Instruments to be used in professional practice should be constantly investigated and updated, in consideration of social, political, and technological evolution. Interdisciplinary research should be encouraged, to develop tools that facilitate the practice of nutritionists and other professionals in the field of food and nutrition.

\section{CONTRIBUTORS}

DT CUNHA was responsible for study design, article writing and data analysis. ALB AMORIM and FHM LEITE were responsible for data collecting and article writing. E STEDEFELDT, VV ROSSO and DH BANDONI were responsible for the study design, writing and critical review of the article.

\section{REFERENCES}

1. Conselho Federal de Nutricionistas (Brasil). Resolução CFN n600, de 25 de fevereiro de 2018, texto retificado 23 de maio de 2018. Dispõe sobre a definição das áreas de atuação do nutricionista e suas atribuições, indica parâmetros numéricos mínimos de referência, por área de atuação, para a efetividade dos serviços prestados à sociedade e dá outras providências. Seção 1, p.68, Diário Oficial da União, 2018.

2. Cunha DT, Rosso VV, Stedefeldt E. Food safety performance and risk of food services from different natures and the role of nutritionist as food safety leader. Ciênc Saúde Coletiva. 2018;23:4033-42.

3. Abreu ES, Spinelli MGN, Pinto AMS. Gestão de unidades de alimentação e nutrição: um modo de fazer. São Paulo: Metha; 2009.

4. Teixeira SMFG, Rêgo JC, Figueiredo AJS. Índices para cálculo de área de Unidades de Alimentação e Nutrição (UAN). Alim Nutr. 1992;4:7-20.

5. Gandra YR, Gambardella AMD. Avaliação de serviços de nutrição e alimentação. São Paulo: Sarvier; 1986.

6. Sant'Ana HMP, Campos FM. Dimensionamento dos setores da Unidade de Alimentação e Nutrição. In: Sant'Ana HMP, editor. Planejamento físico-funcional de unidades de alimentação e nutrição. Rio de Janeiro: Rubio; 2012. p.85-109.

7. Ministério da Educação (Brasil). Dados físicos e financeiros do PNAE 2018. 2017 [citado 2017 jul 5]. Disponível em: http://www.fnde.gov.br/programas/pnae/pnae-consultas/pnae-dados-fisicos-e-financeiros-do-pnae

8. Gomes NAAA, Campos MRH, Monego ET. Aspectos higiênico-sanitários no processo produtivo dos alimentos em escolas públicas do Estado de Goiás, Brasil. Rev Nutr. 2012;25(4):473-85. http://dx.doi.org/10.1590/S14 15-52732012000400005

9. Carvalho NA, Martins KA, Sousa LM. Extra institutional food consumption and food preferences of full-time public school students. Rev Nutr. 2018;31(4):373-84. http://dx. doi.org/10.1590/1678-98652018000400003

10. Cunha DT, Stedefeldt E, Rosso VV. The use of health risk scores and classification in food service: An experience in Baixada Santista's public schools, Brazil. Br Food J. 2014;116(5):753-64.

11. Santana NG, Almeida RCC, Ferreira JS, Almeida PF. Microbiological quality and safety of meals served to children and adoption of good manufacturing practices in public school catering in Brazil. Food Control. 2009;20(3):255-61. http://dx.doi.org/10.1016/j.foodcont.2008.05.004

12. Almeida KM, André MCP, Campos MRH, Díaz MEP. Hygienic, sanitary, physical, and functional conditions of Brazilian public school food services. Rev Nutr. 2014;27(3):343-56. http://dx.doi.org/10.1590/1415-5 2732014000300008

13. Ministério da Educação (Brasil). Resolução CD/FNDE n²6, de 17 de junho de 2013. Dispõe sobre o atendimento da alimentação escolar aos alunos da educação básica no âmbito do Programa Nacional de Alimentação Escolar. Brasília: PNAE; 2013.

14. Stedefeldt E, Cunha DT, Silva Junior EA, Silva SM, Oliveira AB. Instrument for assessment of best practices in school food and nutrition units: From design to validation. Ciênc Saúde Coletiva. 2013;18(4):947-53.

15. Locatelli NT, Canella DS, Bandoni DH. Factors associated with the consumption of school meals by Brazilian adolescents: Results of the PeNSE survey 2012. Cad Saúde Pública. 2017;33(4):e00183615. http://dx.doi. org/10.1590/0102-311X00183615 
16. Carvalho NA, Martins KA, Sousa LM, Díaz MEP. Feeding in full-time public schools: Do students adhere and accept? Rev Nutr. 2017;30(3):357-68. http://dx.doi.org/10.1590/1678-9865201700030000

17. Ghiselli R, Almanza BA, Ozaki MS. Foodservice design: Trends, space allocation, and factors that influence kitchen size. J Foodservice Sys. 1998;10:89-105.

18. Goncalves HVB, Cunha DT, Stedefeldt E, Rosso VV. Family farming products on menus in school feeding: A partnership for promoting healthy eating. Ciênc Rural. 2015;45(12):2267-73. http://dx.doi.org/10.1590/01 03-8478cr20150214

19. Oliveira ABA, Cunha DT, Stedefeldt E, Capalonga R, Tondo EC, Cardoso MRI. Hygiene and good practices in school meal services: Organic matter on surfaces, microorganisms and health risks. Food Control. 2014;40:120-6. http://dx.doi.org/10.1016/j.foodcont.2013.11.036

20. Cunha DT, Fiorotti RM, Baldasso JG, Sousa M, Fontanezi NM, Caivano S, et al. Improvement of food safety in school meal service during a long-term intervention period: A strategy based on the knowledge, attitude and practice triad. Food Control. 2013;34(2):662-7. http:dx.doi.org/10.1016/j.foodcont. 2013.06.003

21. Cunha DT, Rosso VV, Stedefeldt E. Should weights and risk categories be used for inspection scores to evaluate food safety in restaurants? J Food Prot. 2016;79(3):501-6. http://dx.doi.org/10.4315/0362-028X. JFP-15-292

22. Buchholz U, Run G, Kool JL, Fielding J, Mascola L. A risk-based restaurant inspection system in Los Angeles County. J Food Prot. 2002;65(2):367-72.

23. Senado Federal (Brasil). Constituição da República Federativa do Brasil de 1988. Brasília: Senado Federal; 1988.

24. Modesto P. Notas para um debate sobre o princípio da eficiência. Rev Serv Público. 2000;51(2):105-20. http://dx.doi.org/10.21874/rsp.v51i2.328

25. Agência Nacional de Vigilância Sanitária. Resolução RDC n²16, de 15 de setembro de 2004. Dispõe sobre regulamento técnico de boas práticas para serviços de alimentação. Seção 1, p.25, Diário Oficial da União, 2004.

26. Todd ECD, Greig JD, Bartleson CA, Michaels BS. Outbreaks where food workers have been implicated in the spread of foodborne disease, Part 3: Factors contributing to outbreaks and description of outbreak categories. J Food Prot. 2007;70(9):2199-217.

27. Proença RPC. Novas tecnologias para a produção de refeições coletivas: recomendações de introdução para a realidade brasileira. Rev Nutr. 1999;12(1):43-53. http://dx.doi.org/10.1590/S1415-52731999000100004 